\title{
Multicultural Transformation in Wetland Environmental Studies \\ (Wetland Management in Agriculture as a Multicultural Transformation)
}

\author{
Lia Amalia \\ Magister Science Education \\ Universitas Lambung Mangkurat \\ Banjarmasin, Indonesia \\ uchihaliafairuz.la@gmail.com
}

\author{
Muhammad Kusasi \\ Magister Science Education \\ Universitas Lambung Mangkurat \\ Banjarmasin, Indonesia \\ mkusasi@unlam.ac.id
}

\begin{abstract}
Wetlands are inundated areas, either permanently or seasonally. Those areas can be managed properly if there is a proper utilization; i.e. deploying wetlands in agriculture, such as farming. This utilization is very cultivating for the people of Indonesia, especially in South Kalimantan, because most of South Kalimantan people have livelihood as rice farmers. This wetland management is one of the multicultural transformations that sustain the character of Indonesian society. More than $75 \%$ of the rice farming community farms on wetlands due to their flooding arrangements that are consistent with the growth of rice crops. The purpose of this research is to describe wetland management in agriculture as a multicultural transformation. That is, multicultural transformation is not just about different cultures, but also as a process that helps the development of society to realize better development.
\end{abstract}

Keywords: wetland, agriculture, multicultural transformation

\section{INTRODUCTION}

Nowadays, wetland problems are still prolonged controversial issues because the policy on wetland remains unclear, which makes the sustainability of wetlands uncertain and the damage of wetlandsmost unattainable to overcome[1]. Wetlandshave a very important role, not only for the purposes of fisheries but also for plantation and agricultural purposes [2]. Ecologically, the area holds various functions, such as: buffer area, conversion and supply of nutrients, absorbing and reducing flood and habitat for some animal species. Recently wetland functions are increasingly being known, especially since the disappearance and degradation of many wetlands in some areas which have resulted in large losses to the population.

The degradation of wetland occurs due to the increasing population growth which has an impact on increasing demand for land for settlement and agricultural purposes. The main assessment of environmental support is on how much the environment is able to provide support for sustainability of the organisms. This condition requires awareness of all parties to be wiser and see the wetlands from different points of view. Awareness of the importance of balance between the various functions of wetlands will further ensure the sustainability of the fulfillment of social, economic, and environmental sustainability functions. The extent of wetlands and their complex functions show how wetlands have a very important meaning for human life, especially in agriculture as the fulfillment of staple foods.

Indonesia often faces food dilemmas, especially for rice which is the staple food of most of its people. Supporting stability of rice availability, the government seeks to increase rice productivity through optimal subland utilization. Indonesia is an agrarian country that always faces food problem especially rice as an endless dilemma. The classical reason that tells rice imports are carried out to maintain the national rice supply is due to an imbalance between the rate of rice production and the consumption of rice. The availability of rice independently which is not dependent on imports is an effort towards food stability.

Indonesian Statistics (2012) indicated that the production of dry unhulled paddy (GKG) in 2011 was 65.38 million tons, or when converted into rice with 61 percent yield has produced as much as 39.88 million tons of rice. The production was generated from rice crop area of 13,244,379 hectares with an average productivity of 4,944 tons per hectare. National rice consumption to meet the needs of Indonesia's population of 237 million people, with the consumption of rice per capita of 139 kilograms, required 34 million tons of rice. From the statistics, Indonesia in 2011 should surplus rice about 5 million tons, but in fact Indonesia still requires the import of 2 million tonsof rice. Rice needs of Indonesia by 2020 will be in line with the ever-increasing population growth of around 37 million tons [3]. In real terms, considering the data on rice consumption in 2011, accompanied by an increase in rice consumption in 2020 , to meet consumption outside the national rice supply reserves, an additional supply of national consumption of 3 million tons is required. 9.53 million wetlands in Indonesia have potential for agricultural land, with 6 million hectares potential for food crops 
and 4.186 million hectares which have been reclaimed for various uses, especially transmigration [4].

Based on these data, land utilization especially wetlands is indispensable as an effort to the management of rice crops to meet community needs. The total area of wetland in Indonesia is about 21 million hectares, and about 6.06 million hectares can be allocated for rice crops [5]. Until 2035 wetlands which can still be used for rice crops are about 2.0 to 3.5 million hectares [6]. The extent of wetlands which cannot be utilized properly can suffer from damages if they are not managed in proper and integrated manners. The utilization of wetlands should be carefully planned and designed with long-term perspective of land use principles [7].

An appropriate wetland management in agriculture is a form of multicultural transformation, which states that agriculture which used to be conventional as a culture of Indonesian society can be renewed to be modern with the existence of various tools used as media for cultivation in farming. The existence of such transformation is caused by the development of science and technology that bridge the mindset of the society to a more advanced and practical manner. The advancement of education of a nation is also the basis of the development of democracy. In line with the rising level of education, there is enlightenment of the life of a nation and state. In the preamble of the 1945 Constitution, it is stated that one of the main goals of independence is to develop the intellectual life of the nation. The development of intellectual life of the nation also means to build a society based on science.

\section{DISCUSSION}

Wetlands include a diversity of ecosystems and many types of land, including forest wetlands, peat swamps, fens, wet meadows and saltmarshes [8]. While the Ramsar Convention defines: Article 1.1: "wetlands are areas of brackish, swamp, peat, or water, natural or artificial, permanent or temporary, with running or silent water, bargaining, or salt, as well as areas with seawater whose depth at low tide does not exceed 6 meters. "Article 2.1:" the wetlands may also include riparian (river banks) and coastal areas adjacent to a wetland, islands, or parts of the ocean deeper than 6 meters deep covered by wetlands." [9]

The Ramsar Convention, or the Convention on the Wetlands the Importance of the International, especially as a Drowning Water Habitat, is an international agreement on the provisions of important wetland areas. The objective is to register wetlands of high importance in international level, to promote their wise uses, and to eliminate the deterioration of economic, cultural, scientific, and tourism-related highvalue damage, with the ultimate goal of conserving these areas; the world's wetlands. Countries that are members of the Ramsar Agreement must have at least one wetland location within its territory on the "internationally important list of wetlands", commonly called the "Ramsar Register". Member countries have not only the price of the prevailing wetlands, but theymust also build and implement the government's plan to use wetlands in its territory wisely.

Many areas of wetlands are fertile soil, which is often opened, dried and converted to farmland. Agricultural land management in wetlands is common in South Borneo area because most of the population have a livelihood as rice farmers. Wetlands in South Borneo are identical as land that is always flooded. The specific characteristics of land hydro-topography serve as guidelines in the management of agriculture. The rainwater irrigation system and technical irrigation became the pattern of micro water management. The water system in the wetlands is divided into several typologies; typology A, B, C, and D. The classification of wetlands based on hydro-topography is:

1. Land category A: land can be flooded through the tidal water either the maximum tide (spring tide) or the minimum tide (neap tide).

2. Category B land: land can be flooded during high tides only and lasts between 6-8 months in one year.

3. Land category $\mathrm{C}$ : land cannot be flooded regularly through tide but groundwater can be controlled on ground condition or reach one year plant root zone.

4. Land category D: The land cannot be flooded through tidal or low tide and groundwater is often away from the root zone of plants a year $(>70 \mathrm{~cm}$ below ground level).

Wetlands management is important to be studied because it is a protected area of cultivation by the government. This is in accordance with Government Regulation Law No. 16 of 2004 on stewardship of the soil article 4 states that one of the protected cultivation areas is an agricultural area that includes wetland agriculture [11]. Wetlands more specifically peatlands are very much in line with utilization in fisheries and agriculture [12]. Borneo is a large island; most of its land area is dominated by peatlands. Peatlands in South Borneo is a basin area in the lowlands which in the rainy season is flooded by flood waters from the river or rainwater collection while in the dry season the water becomes dry. Most of the peatlands in South Borneo are swamp areas that need a management to be utilized in agriculture. Data Typology of Borneo peat land dispersal can be seen in Table 1 [13].

TABLE 1. DATA TYPOLOGY OF BORNEO PEAT LAND DISPERSAL

\begin{tabular}{|c|c|c|c|c|c|}
\hline \multirow{2}{*}{ Land Typology } & \multicolumn{4}{|c|}{ Type of Overflow } & \multirow{2}{*}{$\begin{array}{c}\text { Total } \\
\text { Area (ha) }\end{array}$} \\
\hline & A & $\mathrm{B}$ & $\mathrm{C}$ & $\mathrm{D}$ & \\
\hline Land of Saline & 11.884 & 799 & - & - & 12.683 \\
\hline Acid Sulphate & - & & 18.715 & - & 18.715 \\
\hline $\begin{array}{l}\text { Sulfate } \\
\text { Potencial }\end{array}$ & 36.257 & 15.545 & - & - & 51.802 \\
\hline Potencial Land & 54.690 & 68.916 & 56.379 & 2.612 & 182.597 \\
\hline $\begin{array}{l}\text { Potencial } \\
\text { Peatland } \\
\end{array}$ & 805 & 3.090 & - & - & 3.895 \\
\hline Shallow Peat & 52.787 & 12.080 & 17.268 & - & 82.135 \\
\hline Mediaum Peat & 5.000 & 5.331 & 11.655 & - & 21.986 \\
\hline Deep Peat & 205 & 2.208 & 9.446 & - & 11.859 \\
\hline Very Deep Peat & - & - & 235 & 177.273 & 177.508 \\
\hline Other (lake) & 68 & - & & & 68 \\
\hline & 161.696 & 107.969 & 113.698 & 179.885 & 563.248 \\
\hline
\end{tabular}


Physical characteristics of peatlands are very important in their use for agriculture. Physical properties of peat land) include moisture content, bulk density (BD), bearing capacity, subsidence, and irreversible drying. Physical properties to note in relationship to the conservation of peat soil are the presence of water content. Peat soil water levels ranging from 100 to $1300 \%$ of the dry weight (13 times the weight) causes BD to be low. Bulk density is related to the level of maturity and mineral content, where the more mature and the higher the mineral content is, the greater the BD and the more stable peat soil are (not easily damaged) [14].

The chemical characteristics of peatlands are largely determined by the content, thickness, and type of minerals on the substrate (on the peat base), as well as the rate of peat decomposition. Mineral content of peat in Indonesia is generally less than $5 \%$ and the rest is organic material. The organic fraction comprises humane compounds of about 10 to $20 \%$ and most other compounds are lignin, cellulose, hemicellulose, waxes, tannins, resins, suberins, proteins, and other compounds [14]. The chemical composition of peat is strongly influenced by the parent material, the degree of decomposition and the chemical properties of the original environment. The liquid phase of the peat consists of aliphatic and aromatic organic acids having active functional groups such as carboxyl, hydroxyl and amine. The characteristics of these organic acids will determine the chemical properties of peat.

When organic acids from peatlands are high, the soil reactions are generally acidic. However, since the organic acid is a weak acid, the soil $\mathrm{pH}$ usually ranges from 4-5. Soil $\mathrm{pH}$ may be lower when there is an oxidized sulfidic layer or peat formed on very poor soil layers such as quartz sand. The level of phenolic acid in peat in Indonesia is very high. P-hydroxy benzoic acid, kumarine acid and ferulic acid of 32.4 ppm, 34.6 ppm and $35.2 \mathrm{ppm}$ respectively in Air SugihanSumsel peat. While in Berengbengkel, Central Borneo, each of the three phenolic acids was $467.5 \mathrm{ppm}, 140.73 \mathrm{ppm}$ and $15.18 \mathrm{ppm}$.

The high levels of felonic acid in peatlands will cause the soil to become acidic, so there is a need for proper management of the peatlands. Existing peatlands in Indonesia generally contain high phenolic acids that are toxic to plants. Phenolic acid can be lowered by adding $\mathrm{Cu}$ to the treatment until its decrease reaches $80 \%$, to disabling monomer organic acids, adequate polyvalent cations can also increase the peat positive charge so as to adsorb nutrient anions such as phosphate elements [14]. Polyvalent cations can neutralize the acids effectively, so the addition of appropriate doses can increase the productivity of peatlands in a sustainable way.

Land productivity is not only influenced by the element of fostat, but also nitrogen that has an important role for the growth of plants, especially rice plants. Nitrogen plays an important role in promoting rapid crop growth and improving yield and grain quality through increasing number of tillers, leaf expansion, grain formation, grain filling, and protein synthesis. Rice crops lacking nitrogen have little seedlings and stunted growth. The leaves are yellowish green and begin to die from the tip then spread to the center of the leaf [15]. Meanwhile, excessive nitrogen which is given will result in losses such as: softening the straw and causing the plant to easily fall down and reduces the quality of crops.

The wetland management in the field of agriculture does not only consider the macro and micro elements in the soil, but it also pays attention to the water content. Suitable or sufficient water content for plant sustainability can trigger rapid growth. Rice plants require land or soil flooded during vegetative growth [16]. This condition is very possible if rice planting is done on land that has the ability to hold water (watertight) longer. Besides, soil texture helps determine the water system in the soil, in the form of infiltration speed, penetration and ability to bind water by the soil. Soil texture contributes to the soil's ability to hold and absorb water. The suitable soil texture for rice cultivation is a smooth texture with low porosity.

Based on the exposure, proper and appropriate wetland management in the field of agriculture has a very important role in improving the welfare of the community, especially in the South Borneo region, because the agricultural sector provides employment and food for the people around. Moreover, it can also make the area of Borneo as a producer of rice crops. This achievement can only be done if there is awareness and action from the surrounding community to improve the development process as a manifestation of welfare and realize better development. The process of development that happens to be the basis of multicultural transformation will eventually develop and become a culture for the people of Indonesia. The change of wetlands which used to be swamp forests is now being a farming enterprise that has great benefits for the continuity of society.

The changes occurring in such achievements are called transformations. That in the Webster Dictionary it says: "To transform means to change in form, appearance or structure; metamorphoses; to change condition, nature or character; to change into another substance ". It states then that: "That is, while all transformation is change, not all change is transformation. Transformation is a change in kind; not a change in degree" [17]. From this point, it can be understood that transformation means (a) to change form, appearance or structure; (b) to alter the condition, nature or characteristics; even (c) to substitute the substance. It means that all transformations are changes, but not all changes are transformations. Change is more superficial, while transformation is more substantial. Transformation begins with a deep understanding of knowledge, with such an understanding of the individual giving new meaning to life, its events, and its interaction with others. This means that transformation is a change of the individual 
after understanding a deep knowledge, by applying the concept, principle or procedure of knowledge into something more meaningful and useful as survivals.

Briefly stated, multiculturalism can be understood as the recognition that a country or society is diverse and complex or can be interpreted as "trust" to the normality and acceptance of diversity [18]. Multiculturalism contains at least two complex notions of "multi" meaning plural, "culturalism" containing culture. The term plural contains a kind of meaning, because pluralism does not mean recognition of the existence of things that are different, but recognition that has implications political, social and economic. Therefore, pluralism is concerned with the principles of democracy [19].Thus, it can be concluded that multicultural transformation is a change related to science and social, which becomes diversity in society. Multicultural transformation is not only related to norm, value, ethnic diversity, or social status, but also related to wetland management in agriculture. This is because the management of wetlands in agriculture, especially farming can be used as a culture of the people of Indonesia to improve the survival of people's living standards.

\section{CONCLUSION}

Transformation is a change of the individual after understanding a deep knowledge, by applying the concept, principle or procedure knowledge to become more meaningful and useful as survival. The proper transformation of agriculture is a multicultural transformation, which states that the formerly conventional agriculture becomes more modern as a culture that is expected to bridge the mindset of the community especially the rice farmers to a more advanced and to use practical methods. Moreover, the utilization of wetlands becomes more optimal so that the challenges to the availability of food can be answered considering the vastness of unutilized wetland areas.

Multicultural transformation is expected not to be a mere description in the text, but it is applied in order to advance a nation which is also the basis of the development of democracy as stated in the preamble of the 1945 constitution explaining that one of the main goals of independence is to develop the intellectual life of the nation and advance the general welfare of the nation.

\section{REFERENCES}

[1] T. Notohadiprawiro, Lahan Basah. Yogyakarta: UGM. 2006.

[2] J. Davies, G. Claridge, and E.C. Nirarita, Manfaat Lahan Basah: Potensi Lahan Basah dalam Mendukung dan MemeliharaPembangunan. Kerjasama. Bogor: Direktorat Jendral Perlindungan Hutan dan Pelestarian Alam dan Asian Wetland Bureau Indonesia, 1995.

[3] T. Sudaryanto, T. Kustiari, HP.Saliem, Perkiraan kebutuhan pangan tahun 2010 sampai 2050. Buku Analisis Sumber Daya Lahan Menuju Ketahanan Pangan Bekelanjutan. Jakarta: Badan Penelitian dan pengembangan Pertanian, 2010

[4] N. Dakhyar, A. Hairani, L. Indrayati, "Prospek Pengembangan Penataan Lahan Sistem Surjan di Lahan Rawa Pasang Surut". Jurnal Agrovigor. 5(2), 2012, pp 113-118

[5] F. Agus, M. I. G. Subiksa, Lahan gambut: potensi untuk pertanian dan aspek Lingkungan. Bogor: Badan Penelitian Tanah dan World Agroforestry Centre(ICRAF), 2008.

[6] D.W. Rudolf, Lahan gambut potensial untuk pertanian, 2001.

[7] S. Hardjoamidjojom, B. I. Setiawan, Pengembangan dan Pengelolaan Air di Lahan Basah. Buletin Keteknikan Pertanian. 15(1), 2001, pp 40-47

[8] B. G. Fernandez, G. S. Emeterio, Conceptions and Perceptions of Primary School Teachers on Wetlands. Society of Wetland Scientists 2017, Springers, 2017.

[9] A. M. Soenjdjoto,015). Sekilas Tentang Lahan Basah dan Lingkungannya. Prossiding Seminar Universitas Lambung Mangkurat "Pootensi, Peluang, dan Tantangan Pengelolaan Lahan Basah Secara berkelanjutan (Ed. Soenjdjoto, A, M., Dharmono) first printed 2016, 2015, pp 1-20

[10] S. Hardjoamidjojo, B.I. Setiawan, Pengembangan dan Pengelolaan Air di Lahan Basah. Buletin Keteknikan Pertanian. 15(1): 2001, pp 40-47.

[11] Permen, Penatagunaan Tanah. Jakarta: Peraturan Pemerintah No. 16, 2004

[12] B. Saputra, (2014). "Keseuaian Padi Sawah Dilahan Gambut Politeknik Pertanian Negeri Payakumbuh”. Jurnal Nasiona 1Ecopodon JNEP Vol. 2 No. 1, 2014, pp 7-11

[13] A. D. Suriadikarta, M. T. Sutriayadi, "Jenisi-Jenis Lahan Berpotensi Untuk Pengembangan Pertanian Di LahanRawa". Jurnal Litbang Pertanian, 26(3), 2007

[14] N. S Ratmini, Karakteristik dan Pengolahan Lahan Gambut Untuk Pertanian. Jurnal Lahan Subotimal Vol. 1, No. 2, 2012, pp 197-206.

[15] P. S. Patti, E. Kaya, C. Silahooy, Analisis Status Nitrogen Tanah Dalam Kaitannya Dengan Serapan Netrogen oleh Tanaman Padi Sawah Di DesaWimital, Kecamatan Kairatu, Kabupaten Seram Bagian Barat. Agrologia, Vol, No. 1, 2013, pp 51-58

[16] M. Tufaila, S. Alam, Karakteristik Tanah dan Evaluasi Lahan Untuk Pengembangan Tanaman Padi Sawah di Kecamatan Oheo Kabupaten Konawe Utara. AGRIPLUS, Vol. 24, No. 2, 2014.

[17] M. Dazko, K. Macur, S. Sheiberg, Transformation: Adefinition, theory and the challenges to transforming, 2014.

[18] Baidhawydan Zakiyuddin, Pendidikan Agama Berwawasan Multikultural. Jakarta. Gelora Aksara Pratama, 2015.

[19] H. A. R. Tilaar, Perubahan Sosial dan Pendidikan: Pengantar Pedagogik Transformatif untuk Indonesia, Jakarta: Grasindo, 2002. 